\title{
Death-related expressions in Javanese angkating layon speech and English eulogy
}

\author{
Aris Munandar \\ Department of Intercultural Studies, Faculty of Cultural Sciences, Universitas Gadjah Mada. Jl. Sosiohumaniora No. 1. \\ Bulaksumur, Yogyakarta.
}

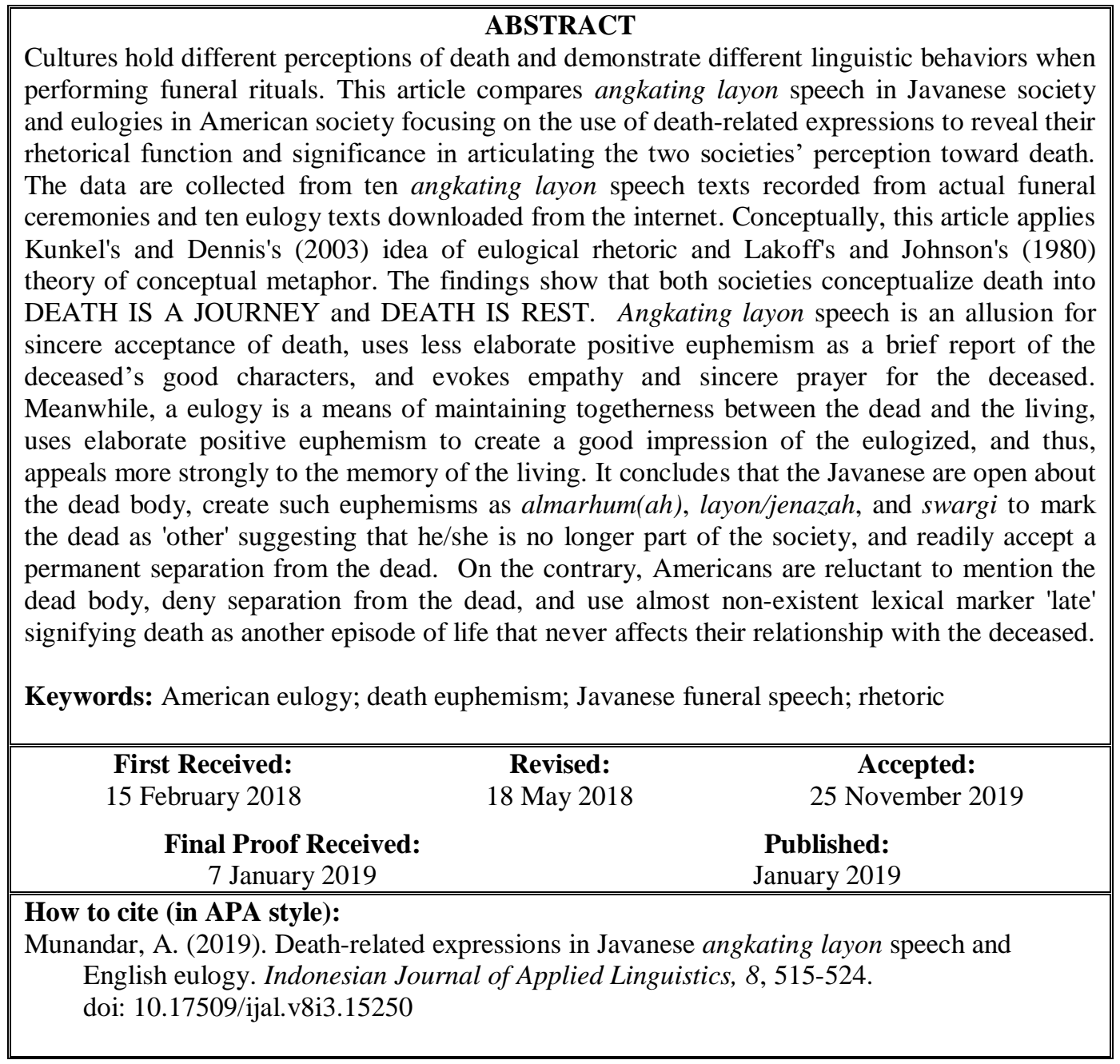

\section{INTRODUCTION}

We have witnessed changes in many aspects of life, but our fear of death remains unchangeable. "Death is still a fearful, frightening happening, and the fear of death is a universal fear even if we think we have mastered it on many levels." Kübler-Ross (2009, p. 4). If we continue having a fear of death without means to avoid it, how do we deal with it? In Javanese society where death is generally perceived as a natural part of the life cycle, people can accept the death of a beloved more easily.
The remark "everything from God will return to Him" is frequently made upon hearing of a death, regardless of the religion of the deceased (Subagya, 2004, p. 83). Unlike the Javanese, Americans perceive death as a "failure to maintain life" (Laderman, 2003) leading to a general attitude of "denial toward death" (Essman, 2014). How are their different attitudes toward death reflected in funeral speeches?

Taking death as a natural part of the life cycle, Javanese people feel at ease when discussing death, 
even in the presence of the bereaved. They expect that an angkating layon speech mentions death, the dead, dead body, and burial. The use of a direct way will not cause an offense to the audience. On the contrary, seeing death as a failure of the dead, American society face the death of a beloved with much regret and deep pain. To mitigate the pain, they avoid talking about death, dead body, or burial. When one needs to talk about them in the presence of the bereaved such as when delivering in a eulogy, one will do it in most tactful and indirect ways by means of the euphemism "[to] show concern for the feelings of our fellow human beings" (Abbott, 2010, p. 51). A linguistic study on the set of death-related expressions used in funeral speeches in Javanese and American cultures will reveal the rhetorical function of funeral speeches and the perception toward death in each culture.

Previous studies on funeral speeches across culture and time reveal that they are carefully crafted (see Farghal, 1995; Fernández, 2006; Kunkel \& Dennis, 2003;) and carry heavy social, economic, and political messages (Stevanović, 2009; Warambo, Odero, \& Suleh, 2015). Studies also reveal various attitudes toward death (see Bailey \& Walter, 2016 for conquest of death; Essman, 2014 for denial toward death; Nyakoe, Matu, \& Ongarora, 2012 for a negation of death). Euphemisms of death have also been extensively researched both in a single culture (Crystal, 2014 on English euphemism for death; Herat, 2014 on death notion in Sri Lanka; Nyakoe, et al., 2012 on conceptualization of death in EkeGusii euphemism; Pound, 1936 on American euphemism for dying, death and burial) as well as in comparison of two cultures (Gomaa \& Shi, 2012 for death euphemism in Egyptian Arabic and Chinese; Rui, 2010 for English and Chinese death euphemism) or even studied cross-culturally (Palgi \& Abramovitch, 1984). However, research on euphemisms in a funeral speech in Javanese society has not received equal attention. What is abundant in the literature is slametan (review in Boogert, 2017). A brief account on funeral service in Javanese society is available from the earlier publication by Geertz (1973) as part of his studies on Javanese culture. A more comprehensive account on death within the Javanese culture constellation is available in Subagya's ethnographic study on death (2004). It reveals that death in the Javanese people's conception is "not seen as an end that consumes one's life, rather as a passive process that one has accomplished within a certain extent of life. Both Geertz (1973) and Subagya (2004) did not analyze texts produced for the funeral service. So far, a comparative study on Javanese and American funeral speeches has not been conducted. This article addresses two questions related to death in two cultures: how Javanese and American euphemize die, death, the dead, dead body, burial, and grave in their angkating layon speech and eulogy, and how their linguistic practices index their perception toward death. The answers to these questions will be expanded upon below to explain these societies' differences and similarities in perceiving death.

\section{Angkating layon speech and eulogy}

Funeral ceremony in the Javanese society is generally called angkating layon. The name suggests the departure (angkat-ing) of the deceased (layon) from home to the grave. Strong adherents of Javanese custom might follow with a series of postfuneral rituals to pray for the dead (or slametans) because of their significances for the community (Boogert, 2017; Kistanto, 2016). With the rising awareness of Islam, it is performed today under a strong influence of Islamic teachings, and no longer followed with slametans. In predominantly non-muslim regions, however, it remains purely Javanese, and the slametan continues.

Angkating layon among Javanese speech society demonstrates some invariant speeches as an expression of respect by condolence sayers to the dead and the bereaved family, and vice versa. They are generally short due to a commonly held belief under the Islamic influence that a funeral ceremony should be brief to allow immediate internment. The first speech is by a member of the bereaved family which contains an expression of gratitude to the condolence sayers for their sympathy and the neighbors for their assistance, appeal for forgiveness for the dead, and transfer of responsibility from the dead to the survivors. The second speech is a response by a representative of the condolence sayers. The speeches share similar structure and expressions that reveal a unified collective perception toward death among the Javanese society.

Eulogy in American society is a way to acknowledge the life of a person who has died, delivered by a family member or a close family friend. Regarding the significance of eulogy, Davies (2002, cited in Bailey \& Walter, 2016, p. 153) argues that 'words against death' in the funeral ritual is powerful because they give back the energy of life to the mourners in the face of death. He further elaborates the words that can transform the mourners into living more strongly include words of comfort to the grieving, words proclaiming the religious meaning of death, words evoking any 'significant realm' in which death may have a meaning, words assuring that death will not have been in vain, poetry expressing loss and survival, and words incorporated into music and drama (p.154). These words also reveal the American society's perception of death.

\section{(Death) Euphemisms}

In a narrowed scope definition, euphemism is "a way to convey something without saying a specific word that may be considered too blunt or direct" (Heerema, 2018). Broadly defined, euphemism is any word or phrase that substitutes for another word or phrase that makes us uneasy (Keyes, 2010). In the context of death, euphemism is "an attempts to evoke gentle emotions to find in death and burial a melancholy romance or noble dignity" (Pound, 1936, p. 196) and "are routinely 
employed as a linguistic device for holding the emotional distress elicited by bereavement at arm's length" (Brennan, 2014, p. 192). Today, euphemisms for death range from the solemn and dignified to the jocular and mischievous (Crystal, 2014). Jocular euphemisms for death are regarded by Pound (1936) against the tradition of sentiment. Crystal (2014) identifies sources of euphemisms in the Bible, classical texts, Greek mythology, Latin, shipping, livestock industry, pastimes, mining, finance, and wartime. Euphemisms also vary in style; some example of the contrast between formality and solemnity with colloquialism and slang are given by Crystal (2014): "yield the ghost," "expire," and "pass away" versus "go off the hooks," "kick the bucket," and "zonk."

\section{METHOD}

\section{Data collection}

Euphemisms and non-euphemisms for death and dying were collected from ten angkating layon speeches recorded from actual funeral services performed by the Javanese speech community in Yogyakarta during the 2011-2012 periods, and ten eulogies downloaded from several websites some of which also provide an audiovisual recording of the funeral service to verify that the eulogies are original. The eulogies were selected to represent different circles in American society, which are a politician, athlete, soldier/ firefighter, artist, and religious figure. The angkating layon speeches were transcribed orthographically, while the transcript of the eulogies is available from the websites.

The research focused on the identification of death-related expressions and their context. It aims at recognizing the euphemism types in angkating layon speech and eulogies.

\section{Data classification}

The data are classified into euphemism or noneuphemism type. A further classification of euphemisms follows Conzelmann, Hernandes, and Sherpa ("Euphemism for death"), who divide death euphemism into five types, which are general, religion, medical, murder/suicide, and related term.

\section{Data analysis}

The data analysis involves 1) studying the context of the identified death-related expressions and interpreting the speakers' intentions of use, and 2) comparing the findings of the analysis and inferring the two societies' perceptions toward death. The first applies the concepts of eulogical rhetoric (Kunkel \& Dennis, 2003) that eulogies should respond to the target audience's situation and expectations, and the second applies the conceptual metaphor (Lakoff \& Johnson, 1980).

\section{FINDINGS AND DISCUSSION}

In line with the research questions, the first part of this section is death related expressions and their rhetorical function in both angkating layon speech and eulogy, and the second part is an interpretation of the two societies' perception toward death.

Both Javanese and American societies share the death repertoire containing a set of expressions for 'dying,' 'death,' 'dead person,' 'dead body,' 'burial,' and 'grave.' Table 1 shows that angkating layon speeches explore all the sets, while eulogies restrict the use of expressions for dead body and grave. However, the comparison (Table 2) reveals that the eulogy uses more types of a euphemism than the angkating layon speech.

Death-related euphemisms in angkating layon speech Angkating layon speech uses various euphemisms for die, death, burial, and grave, which are discussed in the followings.

\section{Euphemisms for 'die'}

Six euphemisms for 'die' share the invariant core meaning "returning to God the Creator" under the category of religion. The underlying belief is that the soul unites with the origin of existence 'sangkan paraning dumadi' (Subagya, 2004, p. 181) rather than decaying with the body, and departs to the world of eternity; death becomes a means for human to reach the perfection of life (Subagya, 2004, pp. 75-77). Death bestows a new status for the dead person becoming more respectable than any living person. All previous statuses are replaced with an image of glorified life. This concept is clearly an influence of Islam and Christianity. The metaphors involve God's names recognizable among the Javanese such as Alloh (Arabic), Pangeran or Gusti (Javanese), and Gusti Alloh (Javanese+ Arabic) with such an attributive noun/adjective for glorification as Subhanahu wata'ala (Arabic 'the most magnificent and the highest'), ingkang Maha Kuwaos or ingkang Murbeng Agesang (Javanese 'the Almighty' and 'the Creator of life'). The choice of God's name regards the audience's expectation: pious Muslim community prefers Alloh Subhanahu wa ta'ala (Alloh for short); ordinary Muslim community prefers Gusti Alloh; non-Muslim community or Javanese-Islam community prefers Pangeran or Pangeran Ingkang Maha Kuwaos, or Gusti ingkang Murbeng Agesang. The rising awareness of Islam in today Javanese results in the diminishing appeal of the local terms Gusti and Pangeran due to the fear of comparing God with deity or human. They continue to be in use, but more likely among ordinary Muslim groups or Christians.

The passive forms (kapundhut 'being taken,' or katimbalan 'being called') imply the absence of men's free will consistent with the Javanese belief that humans are puppets dependent on the hands of the puppet master. Being strongly influenced by Islam and Christianity, the euphemisms emphasize the afterlife in death. Therefore, the saying "went to be with God" should be understood not as an avoidance tactic by the 
Javanese society, but a shared reminder of the comfort found in their belief (c.f. Heerema, 2018).

\section{Euphemism for 'death'}

"Kapundhutipun" in "Kapundhutipun almarhum” ('his passing') is a derivative noun from the passive verb kapundhut ('being taken') and the suffix -ipun. It is the only euphemism for one's death. Another form exists -sedanipun from seda 'die' and the suffix -ipun + nasalization, but is hardly used in angkating layon speech due to its incongruence with the passive forms kapundhut and katimbalan.

Table 1. Death-related expressions in angkating layon speeches and eulogies

\begin{tabular}{|c|c|}
\hline Euphemisms in angkating layon speeches & Euphemisms in eulogies \\
\hline $\begin{array}{l}\text { Die: } \\
\text { - Kapundhut wangsul dhateng ngarsanipun Alloh SWT } \\
\text { (being taken home to meet God) } \\
\text { - katimbalan dening Pangeran Ingkang Maha Kuwaos } \\
\text { (being called by God the Almighty) } \\
\text { - Kapundhut kondur ing Ngarsanipun Gusti } \\
\text { (being taken home to meet God) } \\
\text { - Katimbalan marak ing ngarsanipun Pangeran, } \\
\text { (being summoned before God) } \\
\text { - Katimbalan marak sowan ing Pangayunaning Gusti } \\
\text { Allah ingkang Murbeng Agesang } \\
\text { (being summoned to the protection of God the Creator } \\
\text { of life) } \\
\text { - - Kondur wonten ngarsanipun Alloh SWT } \\
\text { (returning home to meet God) }\end{array}$ & $\begin{array}{l}\text { Die: } \\
\text { - summoned to eternal life beyond all striving, where } \\
\text { everywhere is peace } \\
\text { - } \text { returns home to the place where it all began... } \\
\text { - } \text { accomplished a kind of spiritual leaving } \\
\text { - off you go, escorted by an army of angels to your } \\
\text { Heavenly Father } \\
\text { - go in peace } \\
\text { - rest in greatness } \\
\text { - his noble soul rests in peace } \\
\text { - only waits for us in another place } \\
\text { - } \text { is resting, singing with the angels } \\
\text { - } \text { is a beating pulse in the center of every person he } \\
\text { touched } \\
\text { - is now serving us from the other side... } \\
\text { - is gone } \\
\text { - goes to his grave } \\
\text { - collapsing... } \\
\text { - the dying comfort } \\
\text { - taken from us } \\
\text { - down, will not get up } \\
\text { - wiped out } \\
\text { - the curtain falls } \\
\text { - the drama of their earthly life comes to a close } \\
\text { - } \text { raising the roof like no one has ever before }\end{array}$ \\
\hline $\begin{array}{l}\text { Death: } \\
\text { - Kapundhutipun almarhum (his passing) }\end{array}$ & $\begin{array}{l}\text { Death: } \\
\text { - the loss } \\
\text { - the passing/one's passing } \\
\text { - } \text { a silence that can never again be broken } \\
\text { - the absence of a smile that can never again be seen } \\
\text { - the ugly realities of mortality } \\
\text { - } \text { ultimate sacrifice }\end{array}$ \\
\hline $\begin{array}{l}\text { Dead person: } \\
\text { - ingkang sampun suwargi (who is already in heaven) } \\
\text { - suwargi/swargi (heaven dweller) } \\
\text { - almarhum/almarhumah (late+gender marker) } \\
\text { - alusipun bapak/ibu... (the spirit of Mr/Mrs...) }\end{array}$ & $\begin{array}{l}\text { Dead person: } \\
\text { - late } X\end{array}$ \\
\hline $\begin{array}{l}\text { Dead body: } \\
\text { - layon (the dead's body) } \\
\text { - jenazah (the dead's body) }\end{array}$ & $\begin{array}{l}\text { Dead body: } \\
\text { N/A }\end{array}$ \\
\hline $\begin{array}{l}\text { Burial: } \\
\text { - badhe kasareaken (will be laid) } \\
\text { - tindaking layon ngantos dumugi ing papan palereman } \\
\text { - ingkang pungkasan. (the journey of the deceased to the } \\
\text { final resting place) }\end{array}$ & $\begin{array}{l}\text { Burial: } \\
\text { - goes to his grave }\end{array}$ \\
\hline $\begin{array}{l}\text { Grave: } \\
\text { - papan palereman ingkang pungkasan (a final resting } \\
\text { place) } \\
\text { - Makam (grave) }\end{array}$ & $\begin{array}{l}\text { Grave: } \\
\text { N/A }\end{array}$ \\
\hline
\end{tabular}

\section{Euphemisms for 'dead person'}

All euphemisms for 'dead person' reflect the Javanese's division of life: alam wadag 'life in bodily form' and alam kelanggengan 'life in spiritual form'. The latter is regarded pure and refine, a better world for purified souls, and of a higher status than the first (Subagya,
2004, pp. 87-88). The euphemisms are ingkang sampun suwargi 'who is already in heaven' or suwargi/swargi 'heaven dweller', and alusipun bapak/ibu... 'the spirit of $\mathrm{Mr} / \mathrm{Mrs} . .$. ' The euphemism 'alusipun' is unique, referring the dead with the spiritual form. 'Alusipun' is a noun derived from the adjective alus 'refine' fittingly 
highlight the purity and impalpability of the spirit. Despite the belief in heaven and hell, angkating layon speech never mentions any term associated with hell.

Except for almarhum(ah) --an Arabic borrowing with gender marker-- all the euphemisms use an indirect referent to the deceased. Alusipun bapak/ibu, for instance, refers to the spirit instead of the deceased. For the Javanese, a dead person is no longer a whole entity of body and soul. Accordingly, the dead are referred to as either a body (inanimate) or a spirit (animate). A linguistic marker Kyai (male)/Nyai (female) addresses the dead as an inanimate following the Javanese habit of naming sacred objects, while Swargi or Almarhum(ah) addresses the deceased as a spirit.

Table 2. Categories of death-related euphemisms in angkating layon speeches and eulogies.

\begin{tabular}{|c|c|c|}
\hline Category & Angkating Layon & Eulogy \\
\hline $\begin{array}{l}\text { General } \\
\text { (transformation } \\
\text { from existence to } \\
\text { non-existence; } \\
\text { presence- } \\
\text { absence) }\end{array}$ & - & $\begin{array}{l}\text { - the loss } \\
\text { - the passing } \\
\text { - one's passing } \\
\text { - (is) gone } \\
\text { - late X }\end{array}$ \\
\hline $\begin{array}{l}\text { Religion } \\
\text { (religious } \\
\text { concept of } \\
\text { creator-creation, } \\
\text { and worldly-after } \\
\text { life) }\end{array}$ & $\begin{array}{l}\text { - Kapundhut wangsul dhateng ngarsanipun } \\
\text { Alloh Subhanahu wa ta'ala } \\
\text { (being taken home to meet God) } \\
\text { - katimbalan dening Pangeran Ingkang Maha } \\
\text { Kuwaos } \\
\text { (being called by God the Almighty) } \\
\text { - Kapundhut kondur ing Ngarsanipun Gusti } \\
\text { (being taken home to meet God) } \\
\text { - Katimbalan marak ing ngarsanipun } \\
\text { Pangeran ing } \\
\text { (being summoned before God) } \\
\text { - Katimbalan marak sowan ingkang } \\
\text { Pangayunaning Gusti Allah ing } \\
\text { Murbeng Agesang } \\
\text { (being summoned to the protection of God } \\
\text { the Creator of life) } \\
\text { - Kondur wonten ngarsanipun Alloh } \\
\text { subhanahu wa ta'ala } \\
\text { (going home to meet God) } \\
\text { - Kapundhutipun almarhum (his passing) }\end{array}$ & $\begin{array}{l}\text { - summoned to an eternal life } \\
\text { - returns home to the place where it all began } \\
\text { - accomplished a kind of spiritual leaving } \\
\text { - off you go, escorted by an army of angels to } \\
\text { your Heavenly Father } \\
\text { - go in peace } \\
\text { - rest in greatness } \\
\text { - his noble soul rest in peace } \\
\text { - is resting, singing with the angels } \\
\text { - He is now serving us from the other side }\end{array}$ \\
\hline $\begin{array}{l}\text { Medical } \\
\text { (concept/technic } \\
\text { al term in } \\
\text { medical science) }\end{array}$ & - & $\begin{array}{l}\text { - collapsing in my mother's arms } \\
\text { - the dying comfort } \\
\text { - a beating pulse in the center of every person he } \\
\text { touched } \\
\text { - the ugly realities of mortality }\end{array}$ \\
\hline $\begin{array}{l}\text { Murder/Suicide } \\
\text { (unnatural cause) }\end{array}$ & - & $\begin{array}{l}\text { - taken from us } \\
\text { - fallen (brother) }\end{array}$ \\
\hline $\begin{array}{l}\text { Burial } \\
\text { (bodily } \\
\text { experience; } \\
\text { internment) } \\
\end{array}$ & - & - goes to his grave \\
\hline $\begin{array}{l}\text { Related Term } \\
\text { (analog to daily } \\
\text { life happening) }\end{array}$ & - & $\begin{array}{l}\text { - down, will not get up } \\
\text { - wiped out } \\
\text { - the curtain falls } \\
\text { - the drama of their earthly life comes to a close } \\
\text { - only waits for us in another place (speaks to us } \\
\text { today from there) } \\
\text { - a silence that can never again be broken } \\
\text { - the absence of a smile that can never again be } \\
\text { seen } \\
\text { - ultimate sacrifice } \\
\text { - raising the roof like no one has ever before }\end{array}$ \\
\hline
\end{tabular}

\section{Euphemism for 'dead body'}

Layon and jenazah are two euphemisms for 'dead body.' Layon is derived from layu (adj) $+-n$ with sound modification in the final syllable. It relates to lelayu, which also derives from Javanese base layu 'wither; decay' literally used for a plant but metaphorically for the human. Jenazah is an Arabic borrowing meaning 'the body of a dead person.' Javanese borrows two Arabic words having similar meanings, i.e., mayit 'a dead person' and jenazah 'the body of a dead person,' but jenazah gains a more pleasant association than mayit. Having a negative connotation 'frightful,' mayit 
is very rarely used, except in the prayer for the dead recited in Arabic.

\section{Euphemism for 'burial'}

Badhe kasareaken 'will be laid,' and tindaking layon ngantos dumugi ing papan palereman ingkang pungkasan 'the deceased's journey until the final resting place' are two euphemisms for 'burial.' The first is more direct, while the latter is circumlocutionary, for it does not use any word directly referring to burial: tindaking layon which literally mean 'the departure of the remains' and papan palereman ingkang pungkasan which metaphorically means 'grave.' The word kasareaken derives from sare meaning 'to sleep,' but the surrounding context dictates a secondary meaning 'rest,' thus, conceptualizing DEATH IS REST.

\section{Euphemism for 'grave'}

Papan palereman ingkang pungkasan 'a final resting place,' and makam 'grave' are two euphemisms for 'grave.' Javanese lerem means 'peaceful.' The euphemism makam is an interesting language phenomenon of specialization in Javanese. This Arabic borrowing originally means 'a place,' then, it gradually earns a new, specific meaning 'grave.' A similar Arabic borrowing is kubur but not used in angkating layon speech. Another Arabic borrowing for the grave is makbaroh, which is gaining a higher frequency of use in death announcement among Javanese.

Angkating layon speeches show consistent use of metaphors for 'die,' 'death,' 'burial,' and 'grave' which conceptualize DEATH IS A JOURNEY and DEATH IS REST. Kapundhut kondur dhateng Ngarsanipun Alloh (being taken home to God) for 'die,' kasareaken (laid down to sleep) for 'burial,' and papan palereman ingkang pungkasan (final resting place) for 'grave' indicate a journey to a place of peaceful rest. They are in dignified and solemn style (see Crystal, 2017).

\section{Death-related euphemisms in eulogies}

American eulogies are more restricted in talking about death-related topics. Most eulogies mention death and some give clues for the cause of death, but they avoid addressing the eulogized as a dead person or referring to his dead body, burial, and grave. On discussing 'die' and 'death,' eulogies use various categories of euphemism as in Table 2.

\section{Euphemisms for 'die'}

The influence of religion is seen in ten out of twentyone euphemisms for 'die' with the notion of 'going'or 'being in a different place,' conceptualizing DEATH IS A JOURNEY and DEATH IS REST (Lakoff \& Johnson, 1980). Returns home to the place where it all began; accomplished a kind of spiritual leaving; off you go, escorted by an army of angels to your Heavenly Father; go in peace; summoned to an eternal life beyond all striving; is now serving us from the other side...; and only waits for us in another place conceptualize DEATH IS A JOURNEY. Rest in greatness; his noble soul rests in peace; and is resting, singing with the angels conceptualize DEATH IS REST. A vast majority of Christians believe in heaven, in which the deceased enjoy the presence of God and loved ones for eternity ("Christianity on the afterlife," 2017). Such words as angels, eternity (eternal life), and Heavenly Father carry strong associations with the afterlife, while another place and the place where it all began have weaker associations.

Despite the established Christianity concept of the afterlife, the new interpretation is possible. The euphemism serving us from the other side denies the idea of an idyllic rest which is seen negatively among American industrial society. The euphemism of $a$ beating pulse in the center of everyone he touches is from medical term motivated by the spirit of giving: 'A beating pulse' signals life, and 'a transplanted heart' saves other's life. In other words, American society challenges the idea of death as an end by asserting that 'death' is a transformation into another form enabling one's to continue the business as usual. The euphemisms down, will not get up; wiped out; the curtain falls, and the drama of their earthly life comes to a close borrow sport- and performance-related terms carrying the sense of temporariness. Crime and disaster are commonly regarded as unnatural causes of death, and the victims are considered brave and innocent. For that, euphemisms ultimate sacrifice; ...fallen (brother); and ...having been taken from us are created to strengthen the senses of sacrifice, bravery, and innocence, carrying a positive association to glory, heroism, and precious property.

The diversity of euphemisms in eulogies reveal influences of not only of religion, but also business, sport, and performance. They also reveal acceptance and denial attitudes. The acceptance is driven by a total submission to God's control over man's destiny, while the denial is driven by human's innate desire to maintain happiness and comfort in life.

\section{Euphemism for 'death'}

Six euphemisms for death in use contain two popular metaphors (see Heerema, 2018) the loss and the passing. The rests characterize "inventions of modern funeral orators or newspaper biographers" (Pound, 1936), which are silence that can never again be broken; the absence of a smile that can never again be seen; an ugly reality of mortality; and ultimate sacrifice. They are synonymous with 'loss' of various kinds: the losses of enjoyable noise, sweet smiles, and precious property, and more sentimental and poetic than those in angkating layon speeches.

\section{Euphemism for 'burial'}

Only one euphemism for burial goes to his grave is found in the eulogies consulted. It suggests that burialrelated topic is even more sensitive to discuss than 'die' and 'death' because it is a bitter reminder of physical separation; it is strongly against 'togetherness' with the dead that the bereaved want to maintain. For many, the presence of the body helps them to accept the loss of a 
relative (Natasha, 2016). Alternative funerals such as cremation may also make burial less relevant to discuss.

\section{Non-euphemism for 'die' and 'being dead' in eulogies}

Non-euphemisms are sometimes in use for death from violent acts, terminal diseases, or while on duty. They express pride of the dead's bravery in facing death or condemnation against the act of violence. Some examples from the data are Brian's death comes at a time of great challenge for police officers across the country (death while on duty); And yet they died nobly and They have something to say to each of us in their death (death from a bomb attack); Coach Van Townsend died on Monday, too young, of cancer and I am sad that Van is dead (death from cancer). Without using any lexical marker for the dead, they address the dead as a living person.

Unlike eulogy, angkating layon speech never uses non-euphemism. The absence of non-euphemism for 'die,' 'death,' 'the dead,' and so on, creates formality and builds solemnity. It supports the general attitude among Javanese that funeral service is a sacred ritual to be performed in due respect.

\section{Rhetorical function}

Imagining "an actual ending of our own life" is hard, and our death is only possible by a "malicious intervention from the outside by someone else" (KüblerRoss, 2009, p. 2). Javanese and American societies show different manifestations of this unconscious mind about death.

Funeral services in today Javanese society remain as described by Geertz (1973), namely without hysterical sorrow created by uncontrollable emotional sobbing or wailing. The atmosphere is calm while everyone restrains from bursting into tears because crying is undesirable. The Javanese understand funeral services as instilling the sense of genuinely accepting death. All euphemisms in use (Table 1) lead to a wholehearted submission to God's control over one's life. It is contrary to "taken from us" in eulogy which suggests individual possession of life. Neither is death seen as "an ugly reality". This attitude of accepting death rather than denying it heals the pain more quickly (see Kübler-Ross \& Kessler, 2014).

The primary function of angkating layon speech is to seek the salvation of the dead. It appeals the audience to witness the dead person's good character, forgive any misdeeds, and pray for the deceased. The lack of urgency in talking about the dead's life in angkating layon speech makes it generally short (approximately 250 words). The audience is content with the brief account, convinced of the dead's good conduct in life, and then deliver their forgiveness and prayer. Forgiveness from as many people as possible guaranty the salvation of the dead. In general, Javanese also prize mutualism, which is translated into sincere forgiveness for the dead in the hope that they will also obtain sincere forgiveness from others in return. A shared sense of responsibility to forgive and pray for the dead helps the speech achieve that goal.

The Javanese create circumlocutionary euphemisms for 'die' in a similar way like Arabic (c.f. Farghal, 1995). One example is Katimbalan marak sowan ing Pangayunaning Gusti Allah ingkang Murbeng Agesang in which only katimbalan (called) and Allah (God) carry the most important idea of death. The rests, marak sowan (to present oneself), ing Pangayunaning Gusti (into God's protection), and ingkang Murbeng Agesang (who is the Creator of life) are modifiers. Another example is kondur wonten ngarsanipun Alloh Subhanahu wa ta'ala 'returning to God, the most glorious and the most exalted.' Ability to produce an exact copy of standard expressions such as these euphemisms is regarded as an exceptional skill among Javanese, which contributes to the angkating layon speech's monotonous rhetorical structure. In addition, being a speaker producing a monologue speech in formal functions is a privilege for only a small group of male members of the society who are considered linguistically capable and socially respectable (Munandar, 2013, p. 101). The same person when delivering angkating layon speech in several different funeral services will very likely repeat the same expressions.

In American funeral services, the eulogy is to celebrate life. For that, it presents a long list of achievements to recall good memories of the eulogized and conceal the unpleasantness of death. As such, they can be quite long containing up to 1,214 words (see Clinton's eulogy for Muhammad Ali "In their own words," 2016). It is personalized, expecting the speaker to have a special, close relation with the deceased such that he/she is able to deliver an impressive, accurate account of the deceased. Unlike angkating layon speech which allows only the formal style and tone, eulogy gives room for various styles and tones. The language may be formal (respectful) to show the speaker's respect for the eulogized, or informal (casual), or even contain laughter-evoking humor to show intimacy. At other times, eulogies can be emotionally overwhelming, bringing both the speaker and audience to tears.

The descriptions of the person's life are often hyperbolic, even sounding too good to be true. The data provide these examples:

- He coached to the final days until collapsing in my mother's arms; and

- $\quad$ They are the martyred heroines of a holy crusade for freedom and human dignity. And so this afternoon in a real sense they have something to say to each of us in their death.

The eulogy's accuracy is important, but its authenticity (the speaker's personal knowledge) is even more so (Bailey \& Walter, 2016). The speaker will "avoid expressing unwelcome facts as an act of kindness" (Abott, 2010, p. 52). For the audience, questioning the truth of the speaker's account is regarded as disrespectful behavior. 
Eulogies also create circumlocutionary euphemisms. An example is victims of one of the most vicious and tragic crimes ever perpetrated against humanity in which "crimes" is the headword modified by other eleven words. The words are carefully chosen to give a special effect to the audience, producing a positive image of 'innocence' which evokes sympathy. An even stronger effect is produced by the description of the crime as inhumane, which transforms the euphemism into an appeal to much deeper sympathy.

Unlike angkating layon speech, eulogy allows greater freedom of creativity to explore a diversity of euphemisms. The spirit of individualism in the American society drives people to seek for fresh expressions in the eulogy that may even deviate a particular standard form. Apart from that, the heterogeneity in American society also contributes to the diversity of death-related euphemisms in eulogies. On the contrary, being part of a collectivistic culture, the Javanese prioritize conformity to the standard form in their angkating layon speech resulting in a monotonous structure.

\section{Perception of death}

All euphemisms in Angkating layon speeches show the dominant influence of religion. Eulogies, on the other hand, use more variety of euphemisms revealing the influence of not only religion but also sport, business, and others. Another difference is the range of topics. None of the eulogies consulted mentions dead body, burial, and grave suggesting that those topics are too sensitive to discuss. Meanwhile, angkating layon speeches use euphemisms layon and jenazah to talk more openly about dead bodies, and papan palereman for a grave. Besides, they have euphemisms suwargi and almarhum(ah) both as pronouns and as attributive. Eulogies have no special pronoun for the dead, and use an attributive adjective 'late' only infrequently; the deceased is addressed in the same way as a living person. The following discussion interprets the perception of death in the two cultures based on those properties.

\section{Javanese's perception of death}

Generally, the Javanese see death as destiny and a test from God, best phrased into cobining Pangeran. It comes from Islam and Christianity that introduce God's predetermination. Through death, He wants to see who, among them, accepts His absolute decision and is able to endure suffering from the loss of a beloved. Accordingly, the Javanese have the expressions nandhang duhkita 'suffering deep sadness' and nampi cobining Pangeran 'facing a test from God.' Preventing lament over the deceased is part of the test, for tears and grieving will make the deceased restless and hesitant to leave the family (Subagya, 2004, p. 129). It is best to help overcome sadness and regret more quickly by talking about death and the dead openly as fact, as well as letting the family know that everyone is willing to forgive and pray for the dead. In turn, when the family finally accept the fact of death, the deceased will be released from any burden and can leave for the afterlife happily.

Islam and Christianity contribute to the Javanese's perception that God creates, and has total control over life. The dominant euphemism 'returning to the Creator' presupposes 'a transition' because of the belief in both religions in the afterlife. It may be a peaceful life, or rest, in heaven as a reward for good conducts, or eternal suffering in hell as punishment for evil conducts. Geertz (cited in Subagya, 2004, p. 87) notes that before the propagation of Islam and Christianity in Java, the Javanese held two different perceptions of death. The first was the disappearance of life after reaching perfection (the body simply turns into dust) and the second is a reincarnation (the soul enters an embryo for rebirth). Javanese who continue to hold a traditional belief (Kejawen) today deny reincarnation. Therefore, the concepts of the afterlife in Islam, Christianity, and Kejawen are harmonious. They differ only in the place of the dead: in heaven or hell ("Heaven and hell in Islam," 2016), in heaven-like place ("Christianity on the Afterlife," 2017), and in alam kelanggengan 'a world of eternity' (Subagya, 2004, p. 95).

Javanese euphemisms of death also imply that death separates the dead and the living. The use of indirect-impersonal terms of address 1) ingkang sampun suwargi, 2) suwargi/swargi, 3) almarhum/almarhumah, 4) alusipun bapak/ibu..., and 5) layon or jenazah creates distance with the dead. Creating distance between the deceased and the living helps realize the impossibility of maintaining togetherness with the deceased.

\section{Americans' perceptions of death}

Americans accept death neither as destiny nor as an end, but as transformation and sacrifice. Seeing death as rest is probably universal (compare Crystal, 2014; Gomaa \& Shi, 2012; Herat, 2014; Nyakoe et al., 2012; Palgi \& Abramovitz, 1984; Pound, 1936; and Rui, 2010). However, Americans extend their value 'action/work orientation' (Kohls, 1984; p. 5) into the afterlife, interpreting it as 'a rest from suffering,' in which the dead are able to develop the potential to achieve higher. It is in line with transformation, or transition, to another life where one does only good things for others. By negating death (see Nyakoe et al., 2012) or conquering death (see Bailey \& Walter, 2016), Americans want to believe that death cannot stop one from contributing to society or pursuing achievements. Moreover, death brings regret because man has to sacrifice his independence, and togetherness with the beloved. Sacrifice can have a positive meaning --voluntary, or a negative meaning --against the 'personal control over the environment' value (Kohls, 1984, p. 2).

The underlying perception of death as not an end (continual togetherness) is reinforced by the use of direct personal terms of address for the eulogized and the marginalized use of 'late.' The eulogy addresses the eulogized with his/her name, kinship terms, or collegial terms so as not to create distance. The marginalized use 
of a lexical marker 'late' for the deceased is to compensate for the desire for uninterrupted togetherness. This denial of death and separation produces eulogies which hardly refer to a dead body. "Non-euphemistic synonyms" (Danglli, 2014) for death and die are in use but only in eulogies for victims of crime or for athletes and other 'brave' professionals.

\section{CONCLUSION}

Death-related euphemisms in angkating layon speeches and eulogies explore words associated with religion. Such words as Gusti, Pangeran, Alloh, almarhum, suwargi, and makam in angkating layon speeches, and Heavenly Father, angel, spiritual leaving, and eternal life in eulogies are linguistic evidence of the influence of religion. Death-related euphemisms in both cultures conceptualize DEATH IS JOURNEY and DEATH IS REST, major concepts on the afterlife introduced by Islam and Christianity. The Javanese emphasize the idea that death is a return to the Creator, which underlies death-related euphemisms in angkating layon speech, and makes the use of euphemisms for 'die,' 'being dead,' 'burial,' and 'grave' show consistency. Meanwhile, the Americans show more variations in both form and idea. They contradict the idea of death as rest with the idea that death cannot stop one from making the contribution. They restrict themselves to talking about the dead body and the burial.

Javanese and Americans share similarities in honoring the dead. Both aim at describing the good sides of the deceased to win audience approval and reaffirm that the deceased was a good person. However, they show different manners in doing so. Eulogies are hyperbolic, while angkating layon speech is modest. If American eulogies appeal the audience to maintain good memories of the eulogized while allowing the use of different tones and style, angkating layon speech asks the audience to forgive the dead by maintaining a serious tone and formal style.

The Javanese see the dead as no longer a whole person to be in line with the idea of the soul and body separation. The deceased is seen as either an object (jenazah) or spirit (alus). A lexical marker in use helps to identify which is being addressed. On the contrary, Americans see a dead person as a living one, hoping that death will not ruin their togetherness. This attitude is strengthened with the use of direct personal addresses for the deceased and the absence of the lexical marker 'late.'

\section{ACKNOWLEDGMENT}

The embryonic form of this article was presented in the International Conference of the Indonesian Linguistic Society (KIMLI) 2016. I am grateful to the anonymous reviewers of this journal for their feedback, and Faculty of Cultural Sciences UGM for the support.

\section{REFERENCES}

Abbott, G. (2010). Dying and killing: Euphemisms in current English. English Today 104, 26(4), 51-52. doi:10.1017//S0266078410000349

Bailey, T., \& Walter, T. (2016). Funerals against death. Mortality, 21(2), 149-166. doi:10.1080/13576275.2015.1071

Boogert, J. V. D. (2017). The role of slametan in the discourse on Javanese Islam. Indonesia and the Malay World, 45(133), 352-372. doi:10.1080/13639811.2017.1345166

Brennan, M. (ed). (2014). The A-Z of death and dying: Social, medical, and cultural aspects. Oxford: Greenwood.

Christianity on the afterlife. (2017). Retrieved from https://www.religionfacts.com/christianity/after life/

Crystal, D. (2014). Language death. Cambridge: Cambridge University Press.

Crystal, D. (2017). Words in time and place. London: Oxford University Press.

Conzelmann, A., Hernandes, M., \& Sherpa, T. (n.d.). Euphemisms for death. Death, Dying and Beyond. Retrieved from http://www.lvc.edu/rel314/euph.aspx

Danglli, L. (2014). Euphemism and lexical synonymy. Anglisticum, 3(5), 30-34

Essman, E. (2014). Life in the USA. Retrieved from http://www.lifeintheusa.com/death/

Farghal, M. (1995). Euphemism in Arabic: A Gricean interpretation. Anthropological Linguistics, 37(3), 366-378.

Fernández, E. C. (2006). The language of death: Euphemism and conceptual metaphorization in Victorian obituaries. SKY Journal of Linguistics, 19, 101-130.

Geertz, C. (1973). The Interpretation of cultures. New York: Basic Books.

Gomaa, Y., \& Shi, Y. (2012). Contrastive analysis of death euphemism in Egyptian Arabic and Chinese. Global Journal of Human Social Science, 12(8), 115.

Heaven and hell in Islam. (2016). Retrieved from http://www.message4muslims.org.uk/muslimdoctrines/qa-the-last-things-eschatology/heavenhell-islam/

Heerema, E. (2018). Euphemisms for dead, death, and dying: Are they helpful or harmful?. Retrieved from https://www.verywellhealth.com/euphemisms-fordead-death-or-dying-1131903

Herat, M. (2014). Avoiding the reaper: Notions of death in Sri Lankan obituaries. International Journal of Language Studies, 8(3), 117-144.

In their own words: Eulogies for Muhammad Ali (2016). Retrieved from https://www.nytimes.com/2016/06/11/sports/lonni e-billy-crystal-bill-clinton-eulogies-formuhammad-ali.html 
Keyes, R. (2010). Euphemania: Our Love Affairs with Euphemisms. New York: Little, Brown, and Company.

Kistanto, N. H. (2016). The Javanese slametan as practiced as tradition and identity. International Journal of Humanities and Social Science, 6(11), 290-295.

Kohls, L. R. (1984). The values American live by. Retrieved from https://careercenter.lehigh.edu/sites/careercenter.le high.edu/files/AmericanValues.pdf .

Kübler-Ross, E. (2009). On death and dying: What the dying have to teach doctors, nurses, clergy and their own families. Axon: Routledge.

Kübler-Ross, E., \& Kessler, D. (2014). On grief and grieving: Finding the meaning of grief through the five stages. New York: Scribner.

Kunkel, A. D. \& Dennis, M. R. (2003). Grief consolation in eulogy rhetoric: An integrative framework. Death Studies, 27(1738), 1-38. doi: 10.1080/07481180302872

Laderman, G. (2003). Rest in peace: A cultural history of death and the funeral home in twentieth century America. New York: Oxford University Press.

Lakoff, G., \& Johnson, M. (1980). Conceptual metaphor in everyday life. Journal of Philosophy. LXXVII(8), 453-486.

Munandar, A. (2013). Pemakaian bahasa Jawa dalam situasi kontak bahasa di Daerah Istimewa
Yogyakarta. Humaniora, 25(1), 92-102.

Natasha, F. T. (2016). The rise of alternative funerals a changing attitude to death. Retrieved from https://deathcafe.com/blog/183/

Nyakoe, D. G., Matu, P. M., \& Ongarora, D.O. (2012). Conceptualization of 'Death is a journey' and 'Death as rest' in EkeGusii euphemism. Theory and Practice in Language Studies. 2(7), 14521457.

Palgi, P., \& Abramovitch, H. (1984). Death: A crosscultural perspective. Annual Review of Anthropology, 13, 385-417.

Pound, L. (1936). American euphemisms for dying, death, and burial: An anthology. American Speech, 11(3), 195-202.

Rui, Z. M. (2010). A Contrastive study of English and Chinese death euphemism. (Unpublished Master's Thesis). Ningbo University: China.

Stevanović, L. (2009). Funeral ritual and power: Farewelling the dead in the ancient Greek funerary ritual. Bulletin of the Institute of Ethnography SASA, LVII(2), 37-52.

Subagya, Y. T. (2004). Menemui Ajal: Etnografi Jawa tentang kematian. Yogyakarta: Kepel Press.

Warambo, J. P., Odero, E. O., \& Suleh, E. (2015). A critical discourse analysis of funeral speeches in Kenya: A case of junior Odinga's Speech. Research on Humanities and Social Sciences, 5(4), 1-6. 